\title{
Policy measures to avert possible modal shifts caused by sulphur regulation in the
} European Ro-Ro sector

\author{
Zis, Thalis P.V.; Psaraftis, Harilaos N.; Panagakos, George; Kronbak, Jacob
}

Published in:

Transportation Research. Part D: Transport \& Environment

Link to article, DOI:

10.1016/j.trd.2019.03.001

Publication date:

2019

Document Version

Peer reviewed version

Link back to DTU Orbit

Citation (APA):

Zis, T. P. V., Psaraftis, H. N., Panagakos, G., \& Kronbak, J. (2019). Policy measures to avert possible modal shifts caused by sulphur regulation in the European Ro-Ro sector. Transportation Research. Part D: Transport \& Environment, 70, 1-17. https://doi.org/10.1016/j.trd.2019.03.001

\section{General rights}

Copyright and moral rights for the publications made accessible in the public portal are retained by the authors and/or other copyright owners and it is a condition of accessing publications that users recognise and abide by the legal requirements associated with these rights.

- Users may download and print one copy of any publication from the public portal for the purpose of private study or research.

- You may not further distribute the material or use it for any profit-making activity or commercial gain

- You may freely distribute the URL identifying the publication in the public portal 
Policy measures to avert possible modal shifts caused by sulphur regulation in the European Ro-Ro sector

This is a pre-print of an article published in Transportation Research Part D: Transport and Environment.

The definitive publisher-authenticated version is available here: https://www.sciencedirect.com/science/article/pii/S1361920918308691

Zis*, T.P.V, Psaraftis, H. N., Panagakos, G., and Kronbak, J. (2019). T Policy measures to avert possible modal shifts caused by sulphur regulation in the European Ro-Ro sector. Transportation Research Part D: Transport and Environment, 70, 1-17

*Corresponding author: tzis@ dtu.dk 


\title{
Policy measures to avert possible modal shifts caused by sulphur regulation in the European Ro-Ro sector
}

\author{
Thalis Zis ${ }^{\mathrm{a}, *}$, Harilaos N. Psaraftis ${ }^{\mathrm{a}}$, George Panagakos ${ }^{\mathrm{a}}$, Jacob Kronbak $^{\mathrm{a}}$ \\ ${ }^{a}$ Technical University of Denmark, Copenhagen, Denmark, \\ *Corresponding Author, tzis@dtu.dk
}

\begin{abstract}
The $0.1 \%$ limit in sulphur content within Sulphur Emission Control Areas as of $1^{\text {st }}$ January 2015 requires that ship operators either use pricier ultra-low sulphur fuel oil, or alternatively install abatement technologies through substantial capital investments. A part of the resulting higher operating costs are passed on to shippers resulting in increased freight rates. These may lead to modal shifts towards rail or road options competing with Ro-Ro operators. Due to the unexpectedly low fuel prices in the period 2014-2016, Ro-Ro operators were relatively unharmed by the new limits, but nascent research has shown that if fuel prices increase some Ro-Ro services may not survive. This paper examines a set of policy options that can mitigate or reverse the negative effects of the lowsulphur regulation. The measures include internalizing external costs of transport, repaying fuel surcharges to shippers, subsidizing technological investments of ship operators, or increasing the landbased costs of transport via levies. To compare their efficacy, total costs are calculated for each measure. The results show that the proposed measures can successfully reduce the negative effects of the regulation but this would entail significant costs. A combination of subsidies towards shippers and ship operators is shown to be effective at reversing potential modal shifts and can be crucial in case of high fuel prices in the near future. The findings of this work can assist operators to develop new strategies and improve the resilience of their network, and regulators designing environmental policies that may have negative implications on certain sectors.
\end{abstract}




\section{Introduction}

According to UNCTAD (2018), maritime shipping carries more than $80 \%$ of freight by volume, offering low cost and low carbon transportation of cargo. Despite the low carbon intensity of maritime shipping, it is less environmentally friendly when other pollutant species are considered. To address these environmental impacts, in recent years more regulations have been introduced. A common attribute of such regulation is that ship owners may need to invest in pollutant abatement technologies or use cleaner fuels that as a result will increase their costs. Some of these costs are subsequently passed on to shippers and passengers, and as a result the cost of maritime transportation can increase. One of the most discussed regulations in maritime transport in recent years has been the introduction of Emission Control Areas (ECAs) and in particular the issues with sulphur emissions. The shipping industry had been particularly vocal on the potential implications of the regulation. In academia there has been a significant increase of papers published dealing with ECAs. Considering only the field of transportation, Figure 1 presents an indicative summary of articles retrieved from Web of Science on a search of the keyword "Emission Control Areas". 


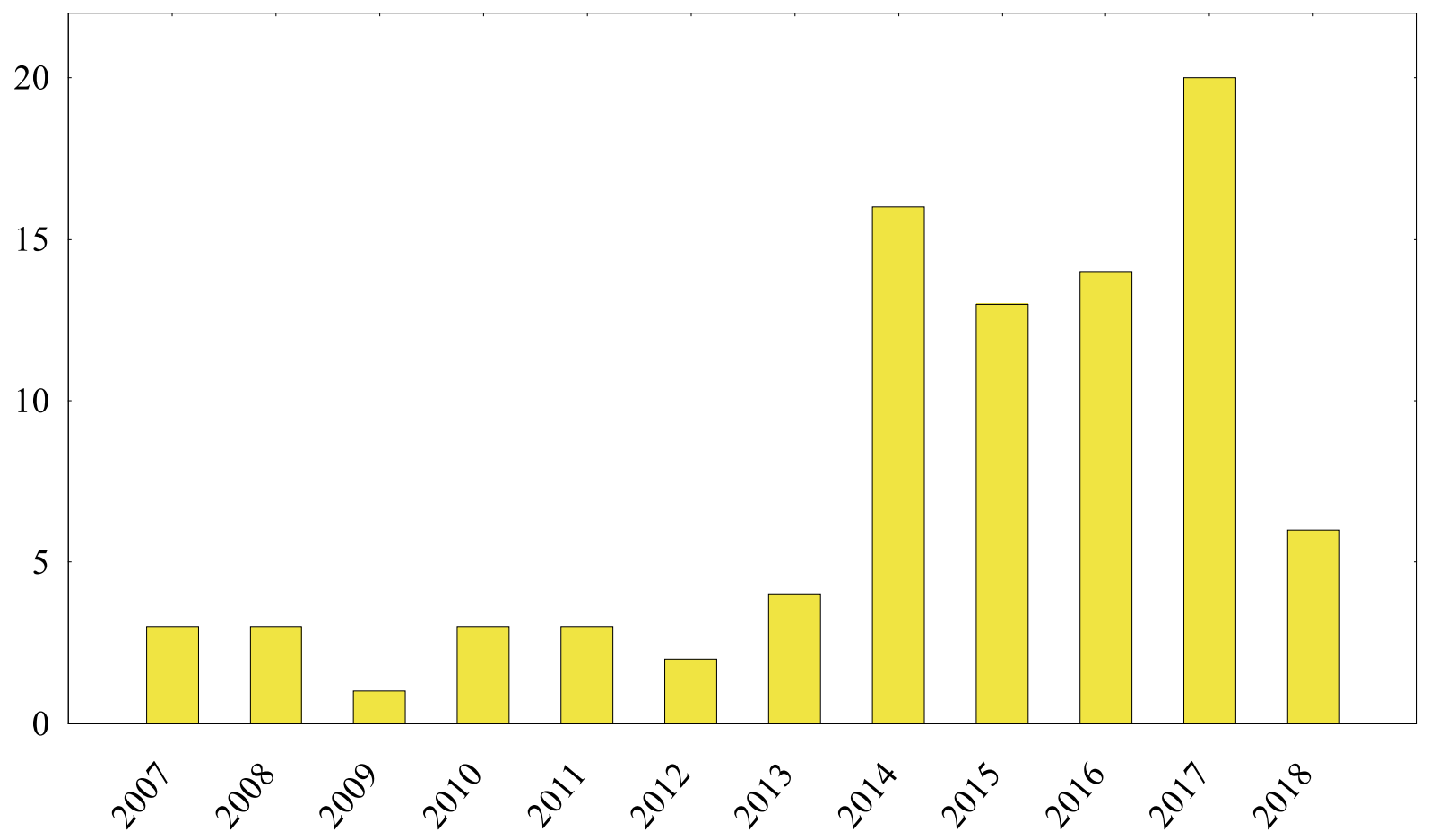

Figure 1: Number of academic articles with a research theme on Emission Control Areas. (Data source: web of science)

It can be easily observed that in recent years analyses of the impacts of ECAs has been a recurring theme in academic literature, with a significant increase since 2014.

\subsection{The new SECA limits and their implications}

The ECAs were introduced by the International Maritime Organization (IMO) as a means to reduce emissions of specified pollutants in these areas. Initially, ECAs were targeting only sulphur oxides and were thus named sulphur emission control areas (SECAs). The first SECAs designated by the IMO was the North and Baltic Sea, and the English Channel, while soon after the US and Canadian coasts followed. For the latter, emission limits on nitrogen emissions were also introduced. In order to reduce sulphur emissions the regulation has set progressively stricter limits on the maximum allowable content of sulphur in fuel used by ships.

Within SECAs, the sulphur limits are lower and a turning point was January $1^{\text {st }} 2015$, where the limit was lowered from $1 \%$ down to $0.1 \%$, versus $3.5 \%$ outside SECAs. Compliance to the new limit is possible only through the use of fuel such as Marine Gas Oil (MGO), Liquefied Natural Gas (LNG), 
or hybrid ultra-low sulphur fuel oil (ULSFO). All of the aforementioned low sulphur fuel types are significantly more expensive than regular Heavy Fuel Oil (HFO). Alternatively, ship operators that have installed scrubber systems to treat the exhaust gases and remove $\mathrm{SO}_{\mathrm{x}}$ emissions could still use normal HFO. These systems require significant capital costs for their installation, and may slightly increase fuel consumption ( 1 to $3 \%$ ), but reduce operating costs in comparison to the use of low sulphur fuels (Jiang et al., 2014; Zis et al., 2016). The main result of the new SECA limits has been the increase of costs for ship operators, and a potentially significant reduction in $\mathrm{SO}_{\mathrm{x}}$ terms.

For certain types of shipping, the impact of the regulation is relatively small as it is proportional to the time spent within SECAs. However, for short sea shipping (SSS) services where the ship spends the entire time or the vast majority within SECAs, the impacts can be severe. Apart from the increased operating costs, there are additional implications of the limits to these services. Part of the increased costs are passed on to shippers, via increases to the so-called "bunker adjustment factor" (BAF). The BAF is a means that all shipping companies use to adjust their freight rates in response to the volatility of bunker prices. In the past, BAFs were determined by Carrier Conferences, however in Europe each company is required to devise its own BAF method, so as to avoid price fixing (Zis and Psaraftis, 2018b). For SSS which is a sector that competes with land-based modes and operates with tight profit margins, an increase to freight rates as a consequence of the sulphur regulation may lead to modal shifts towards other transportation modes. Before the new lower limit, there had been numerous reports depicting a doom and gloom picture for the SSS with closures of services, expansions of rail links, and in general a prediction of a steep decline in transported volumes via maritime links. However, the reality of 2015 and 2016 saw a significant increase in revenue for most ship operators as a result of the unexpectedly low fuel prices. 
The fact that most ship operators caught a "lucky break" makes the discussion on sulphur limits more relevant should fuel prices revert to their previous higher levels. In that case the threat of modal shifts will resurface.

\subsection{On measures to mitigate and reverse the negative impacts of SECA and the global sulphur} cap

The Marine Environment Protection Committee (MEPC) of the IMO confirmed that the global limit of $0.5 \%$ sulphur content will be enforced from January $1^{\text {st }} 2020$. This is expected to place additional pressure on the maritime sector also in areas outside current ECAs, and contingency plans should be in place for all stakeholders involved. It is therefore imperative to propose and examine the viability of measures that can be deployed to ensure that no significant transport volume losses affect the sector. This paper is part of a two year research project on the issue of reversing and mitigating the negative implications of the low sulphur limits. The work expands on work of Zis and Psaraftis (2017) that developed an enhanced modal split model for application in seven routes within SECAs. In that paper, the authors showed that it was only due to the unexpectedly low fuel prices in 2015 that the SSS operators managed to increase their market shares and profitability. Should fuel prices increase again the examined routes would be facing serious challenges and potential devastating losses of market shares towards landbased alternatives. To address such an event, Zis and Psaraftis (2018a) proposed a series of operational measures that SSS operators can utilize in order to cope with the new situation and ensure the viability of their services. In this work, we propose and analyze policy measures that could complement operators' measures, and ensure a smooth transition to a low-sulphur fuel world. The next section will present a brief literature review on SSS and impacts of sulphur limits, whereas Section 3 presents the main methodological framework for the assessment of a set of candidate policy measures. In Section 4 we examine quantitatively the policy options using data from the leading operator that provided data in the paper of Zis and Psaraftis (2017). Section 5 discusses 
the main findings of the policy measures, and considers future challenges ahead of the global sulphur cap.

\section{Literature review}

The majority of academic research in maritime shipping has focused on liner and bulk shipping, with less attention shown to short sea shipping. This can perhaps be attributed to the relatively smaller share of the latter sector in the total fleet. Figure 2 presents the breakdown of the world fleet (above 10000 gross tonnage - GT) as of July 2018.

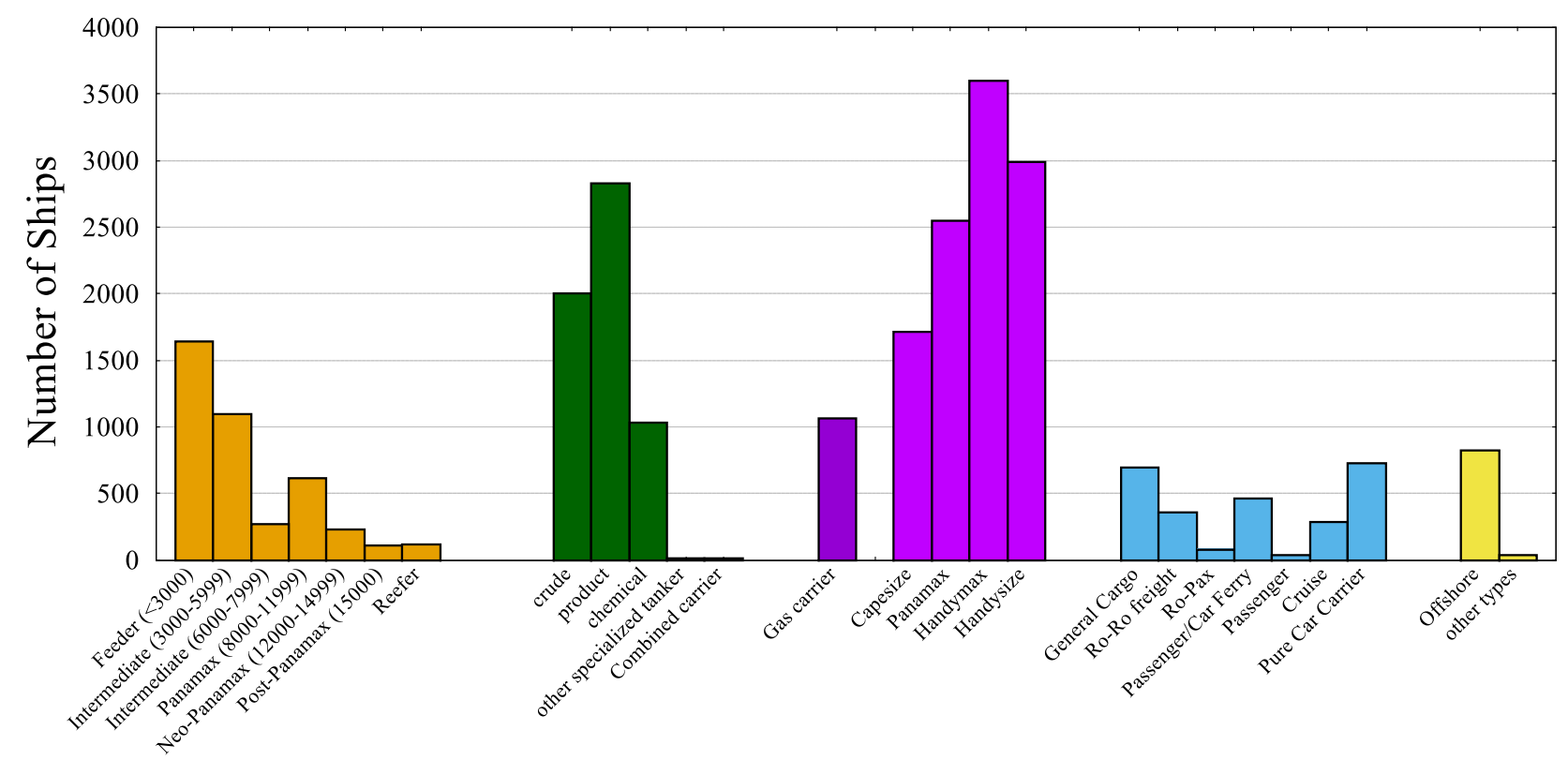

Figure 2: The world fleet breakdown by type (vessels above 10000 GT). Data source: www.clarksons.net

It can be seen that if all subtypes of Ro-Ro vessels are grouped together (including passenger ships, pure car carriers, cruiseships, and Ro-Pax all seen in blue colour) these constitute only $7.67 \%$ of the world fleet (in numbers) whereas containerships amount to $15.6 \%$, bulkers to $42.74 \%$, and tankers to 23.18\%. The next section briefly presents the unique characteristics of short-sea shipping (SSS) and the key challenges the sector is facing under the current stricter environmental limits in place.

\subsection{Short Sea Shipping and focus on Ro-Ro shipping}


Short sea shipping has been given various definitions, but this paper considers it as the transportation of goods and/or people via sea along a coast without crossing an ocean (Bjornland, 1993). By this definition, SSS may include feeder services of liner shipping, bulkers (dry or liquid), and Roll-on Roll-off (Ro-Ro) services. However, in this paper we will focus on Ro-Ro shipping that carries cargoes in trailers, trucks, vehicles, and also Ro-Pax services that additionally transport passengers. Eurostat reports that SSS moved $60 \%$ of total EU-28 maritime transport in 2016, with significant variation from country to country. Figure 3 presents the market share of each mode in tonnekilometres from 1995 to 2015.

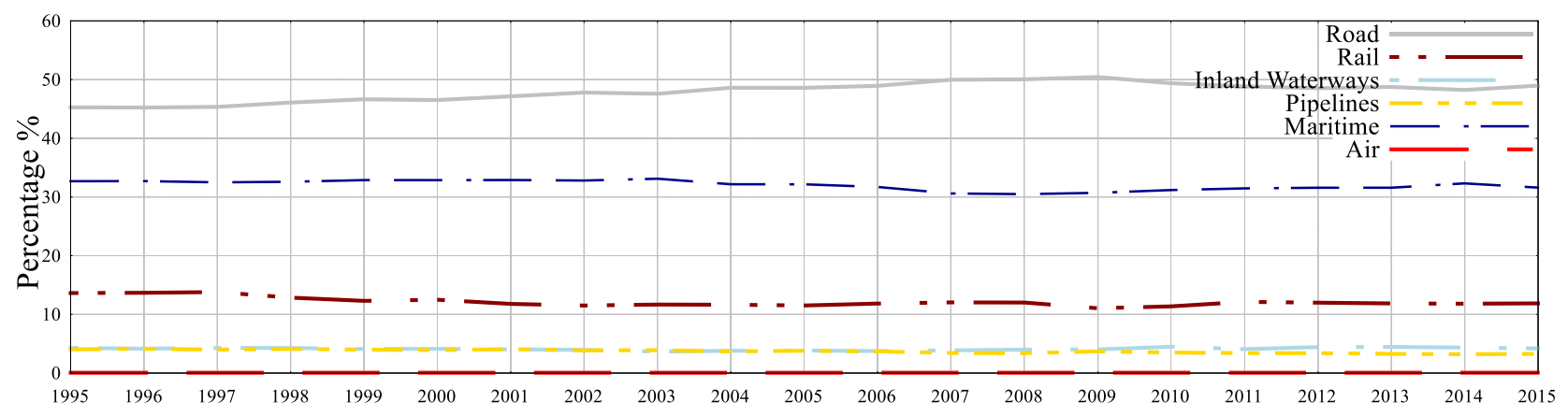

Figure 3: Modal split of freight transport by tonne-kilometres in EU-28. Data source: Eurostat

Figure 3 shows that there is indeed a small increasing trend in the market share of road transport while maritime modes are rather constant around 31\%. In absolute tonne-kilometres, the total transportation has increased by $23.6 \%$ (including a $33.7 \%$ increase for road and a $19 \%$ for maritime) in the same period. The EU supports the development of SSS as a means to reduce road congestion, and aims to move about $30 \%$ of road freight transported over distances longer than $300 \mathrm{~km}$. Therefore, more efforts are required given that road transport has increased its share vs other modes in the last 20 years. Considering the increased bureaucracy and complicated administrative procedures for maritime transport, the additional burden of regulations such as the SECA lower limits can harm the environmental benefits of SSS in Europe and lead to the opposite modal shift of what EU intended. As explained in the introductory part of Section 2, there is relatively scarce research on Ro-Ro shipping, however some of the papers of Section 2.2 were case studies on SSS and Ro-Ro shipping 
in particular. Most studies have either focused on the environmental benefits of Ro-Ro shipping vs land-based options, or on optimization problems such as minimization of operating costs, fuel consumption, delays or maximization of capacity used. Mulligan and Lombardo (2006) propose the further development of SSS as a means to move cargoes away from land-based options, which they quantitatively find to be environmentally worse. They do note that this will not happen on its own, and careful selection of services as well as public subsidies to SSS operators can assist. Medda and Trujillo (2010) conduct a literature review and focus on ways of promoting SSS as a transportation mode to benefit from lower $\mathrm{CO}_{2}$ emissions and improved fuel economy. Paixão Casaca and Marlow (2009) conduct a survey to ask what logistics measures SSS operators could adopt to ease the integration of SSS in multimodal chains. Douet and Cappuccilli (2011) review EU policies that were designed to trigger modal shifts from land-based options to SSS, and identify inconsistencies and an overall unsatisfying performance of these efforts. They find that excluding bulk cargoes as well as captive unitized freight (captive in the sense that these cannot be shipped in a different way due to geography) the potential for modal shifts is minimal. On the issue of moving cargoes away from landbased options towards SSS, Suárez-Alemán et al. (2015) note that some policy measures like the Marco Polo I and II that were designed for this purpose were not as successful and better policies are needed.

\subsection{Research on Emission Control Areas}

Significant academic research has been conducted specifically on the field of ECAs in recent years. There have also been several non-academic studies that dealt with the subject (consulting reports, white papers, and surveys of international associations). The first notable ex-ante study was the consulting report of Lemper et al. (2009) that considered potential modal shifts for some SSS services 
and used a logit model to estimate these. Odgaard et al. (2013) examined the potential extent of increases in shipping costs due to the lower sulphur and nitrogen limits, and found that in some SSS services this could increase up to 20\%. In 2014 a special issue edited by Cullinane and Bergqvist (2014) considered all aspects of impacts of ECAs on maritime transport. The guest editors argued that the designation of additional ECAs could bring more benefits, but also that different policy and regulatory measures are required. In that issue, papers focused on compliance alternatives for the sulphur and nitrogen limits (Jiang et al., 2014; Brynolf et al., 2014), whereas others examined modal shifts as an indirect consequence of the limits (Panagakos et al., 2014; Holmgren et al., 2014). In the aftermath of the introduction of the new sulphur limit more articles have been published in this theme. Zis et al. (2016) showed that due to the very low fuel prices of 2015 the payback period of scrubber systems has been significantly increased. The study by Sys et al. (2016) considered the potential cargo flows moving away from ports within SECAs to ports in the Mediterranean (where there are lowsulphur fuel requirements only at berth, and not during sailing to reach the port), but found more plausible a shift to land-based modes and subsequently potential closures of maritime links. Finally, Zis and Psaraftis (2017) presented an enhanced modal split model that can be applied in SSS and showed that due to the low fuel prices the threat of modal shifts was not realized, but could return in the near future.

On the more operational side of Ro-Ro shipping, Styhre (2009) focuses on ways to improve the capacity utilization of vessels and following a survey states that this is between 75 and $88 \%$ depending on the operator asked. Andersson et al. (2015) note that most fleet deployment papers stem from container shipping, and stress that fleet deployment in Ro-Ro shipping is more difficult due to the increased flexibility of the sector and its services, as well as the differences from ship to ship. They then integrate speed optimization in the planning of shipping routes. From most papers on SSS it is clear that ways to improve its competitiveness are sought after, and that the balance between lower 
costs and increased traveling time (via slow steaming) is the key to achieve this. However, given the increased operating costs as a result of the SECAs, it is important to deploy contingency measures.

\subsection{External costs of transport}

Transport generates negative externalities that involve a cost to society and the economy. In addition to congestion, accidents and environmental impacts in terms of climate change, air pollution and noise, transport activities contribute to the degradation of nature, landscape and sensitive areas, the pollution of soil and water, and aggravate energy dependency (Maibach et al., 2008). Internalization of external cost of transport has been an important policy issue for many years in Europe and elsewhere in the world. From a welfare economics point of view, internalizing external costs aims at efficiency gains through conveying the right price signal to economic actors. The right prices would encourage the use of safer, more silent and environmentally friendlier vehicles, as well as the planning of trips according to expected traffic. With the latest release of the White Paper on transport, the European Commission sets year 2020 as the deadline for the full and mandatory internalization of external costs for all modes with emphasis on road and rail transport (EC, 2011).

Given their importance in the policy dialogue, the external costs of transport and their internalization is a popular subject in literature. Scientific articles on each of the abovementioned externalities suggest a variety of estimation methods pertaining to specific transport modes and, sometimes, specific geographic areas. In general, external costs are estimated by applying a monetary value to the volume of emissions produced. There are two approaches for estimating emission volumes: the top-down one, based on the amount of fuel consumed, and the bottom-up one, based on activity levels (vessel routes or port calls). A discussion on papers supporting one or the other approach appears in Cullinane \& Cullinane (2013). The monetary valuation of externalities, however, is a more controversial issue (Chang et al., 2016). Among the various methods of valuation that have been developed over time, the Impact Pathway Analysis (IPA) is broadly acknowledged as the preferred 
approach for air pollutants, while the avoidance cost approach is regarded as the best practice for carbon emissions (Jiang et al., 2014). Tichavska \& Tovar (2017) provide a recent review of the methodologies deployed for the estimation of external costs from vessel emissions at port. In money terms, Vanherle and Delhaye (2010) estimate maritime external costs that range from $€$ $0.003 /$ tonne-km for bulkers to $€ 0.005 /$ tonne-km for containerships and $€ 0.032 /$ tonne-km for Ro-Ro vessels. The revised external cost calculator used for the EU Marco Polo programme provides estimates that range from $€ 0.00055 /$ tonne-km for an LNG-fuelled dry bulk ship to $€ 0.01963 /$ tonnekm for a high-speed Ro-Ro vessel burning high-sulphur fuel (Brons \& Christidis, 2012).

In order to support its internalization strategy, the European Commission commissioned a study IMPACT - summarizing the existing scientific and practitioner's knowledge on the subject. The IMPACT study resulted in a handbook that contains a generally applicable, transparent and comprehensible model for the assessment of all transport related external costs by all modes (Maibach et al., 2008). Later on, this 2008 Handbook was updated to take into consideration the new developments in research and policy (Ricardo-AEA, 2014). This latter publication is used herewith as the source of the necessary input values.

\section{Methodology}

This section presents the methodological approach that is used to quantify the impacts of the suggested policy measures on the main stakeholders. The paper considers three key players; the ship operator, the shipper, and the regulatory body. The objectives of each stakeholder are briefly presented first, followed by the generalized cost of transport that is the main disutility affecting the shippers' decision making. The section continues with a presentation of the road network model that 
was used to quantify time and cost for shipments in the examined regions, and concludes with a brief presentation of the proposed policy measures that will be examined in the case studies of Section 4 .

\subsection{The three stakeholders and their objectives}

In this work we consider possible policy actions that can reduce the negative impacts of the SECA regulation. In the recent work of Zis and Psaraftis (2017) it was shown that the lower sulphur limits would have resulted in a significant threat to ship operators had it not been for the very low fuel prices of 2015. However, the authors showed that from an environmental perspective the regulation was a success as it managed to reduce SOx emissions, with a very small trade-off with marginally increased $\mathrm{CO}_{2}$ emissions. The regulation thus has affected:

- the ship operators (increasing their operating costs or requiring them to invest in scrubber solutions),

- the society (effects on environment and possible modal shifts with emerging externalities)

- the shippers (increasing their freight rates and potentially leading them to choose other modes)

All stakeholders aim to increase their utility. Ship operators would like to increase their revenue and decrease their costs. Society (under the guise of the regulator in the context of this paper) seeks an improved environmental performance of the transportation system, and particularly in Europe to ensure that SSS remains competitive and actually increases its share versus land-based modes. Shippers simply want to minimize the transportation costs (time and/or actual monetary costs) of their shipments. The balance between the three stakeholders was changed after the introduction of the new sulphur limit within SECAs but the extent of these changes was muffled due to the low fuel prices. In this work policy actions from a regulatory body are considered as a potential response. With regards to the third stakeholder, shippers are considered as followers in the sense that they cannot perform any action to reverse the negative effects of SECAs. We consider that all shippers can do is 
select the mode of transport that minimizes their disutility in the form of generalized cost of transport. However, they cannot take any action to reverse the effects of the SECA regulation; the freight rates they are paying are set by the ship operators and/or haulers, and their profit is not part of the ensuing models.

\subsection{Generalized cost of transport and modal choice}

The generalized cost of transport is considered as the disutility of the shipper and is a function of total transportation costs and time cost. Guelat et al. (1990) suggested that for competition among modes, the generalized cost function should be expanded to include other shippers' objectives (such as delays and time) and that it is possible to aggregate shippers based on the origin. Hanssen et al. (2012) consider that shippers choose the transport solution that gives the lowest generalized costs. Crainic (2000) conducts a review on network design in freight transportation and notes the importance of the reliability of service as well as the productivity of terminal and transportation operations. In this paper where maritime modes are considered the importance of smooth port operations is very important and the time spent on modal changes is considered. Transit time and cost are usually linked through a relationship between the value of cargo, its depreciation rate, and the total transportation time from origin to destination. It should be noted that depending on transportation mode the monetary costs for each shipment may vary in units. For example, in liner shipping the freight rates are quoted in monetary units per TEU, in air freight in monetary units per $\mathrm{kg}$ (Lo et al., 2015), for road and rail modes in monetary units per ton $\cdot \mathrm{km}$. With regards to Ro-Ro shipping, the freight rate is a function of shipment size and not weight, and typically the quotes are given in monetary units per lane-meter $(\mathrm{lm})$ transported. The lane-meter is essentially a measure of how much of the available space on board the vessel the shipment is occupying. In the analysis the generalized cost of transport $G C_{i}(€ / \mathrm{lm})$ of a shipment via transport mode $i$ is calculated via the simplified formulation of Zis and Psaraftis (2017) shown in eq. 1 below: 


$$
G C_{i}=T C_{i}+a \cdot T T_{i}
$$

In eq. $1, T C_{i}(€ / \mathrm{lm})$ represents the total monetary cost that the shipper is paying if mode $i$ is chosen. Parameter $\alpha(€ / \mathrm{lm} /$ hour $)$ is a the value of time and finally $T T_{i}$ is the total transit time if mode $i$ is chosen including all waiting times and time lost due to intermodal changes.

As stated earlier, the shipper is assumed to select the transportation mode that minimizes $G C_{i}$. However, there are various uncertainties (for example unexpected delays, reliability of service, quality of service) that make mode choice a little more complicated. The freight rate may also depend on the quantity transported and the supplier may offer discounts that can reduce operational costs and bring environmental benefits as noted in the work of Zissis et al. (2018). However, in this work we use a fixed freight rate (different for each service) as provided by the collaborating ship operator. To this end, a logit model is used that allows estimating the probability of choosing each mode $i$ among $N$ alternatives. Modal split models have been traditionally used in travel behavior modelling where the decision maker is an individual, but in recent years they have also been successfully used for freight transport (García-Menéndez et al., 2014; Meixell and Norbis, 2008; Zis and Psaraftis, 2017). In this work we adopt the model of Zis and Psaraftis (2017) that uses a nested logit model structure, whereby the shipper first selects between two nests that can be either a maritime $m$ nest, or a landbased $l$ nest. Subsequently, the shipper decides which option $(i / m$ or $i / l)$ to choose within the respective nest. The nested logit model can be calibrated if information on the market share of each option is known, as well as if the generalized cost of transport for each option is retrieved. Calculating the generalized cost is simple if the cargo value, the total transportation time, and the freight rate for each transport mode is known.

\subsection{Road network model}

In the context of this paper, freight rates and value of cargo were provided by the shipping company that assisted in the research project. However, for land-based options a road network model was 
developed specifically for this project. The basis for the road network model is a digital road network for all relevant countries in the Northern part of the European Union. Within the road network model, it is possible to associate a generalized cost of transport on both links and nodes. This makes it possible to model the costs associated with traversing the entire network including cost for e.g. transhipment etc. The road network model has been fully integrated within the geographical information system (GIS) ArcInfo Workstation. GIS road network models for freight transportation over long distances have been used before in the literature (Southworth and Peterson, 2000). Jourquin and Beuthe (1996) provided one of the first notable applications on Trans-European flows that model competition with road, waterways and rail options.

Two steps are involved in modelling the cost of traversing the multimodal transport system: modelling the physical performance of the transport system (driving distances and transport time), and calculating the cost associated with the use of the transport system. Distances and transport times are modelled within the geographical information system. Each road link within the network model includes information on length and speed limits, which is used for calculating the transit time. This is similar to how e.g. car navigations systems and web-based route finding tools work.

The calculation of road transport costs, however, heavily depend on the flow speed on each link. Assuming free flow conditions corresponding to speed limits will definitely improve the performance of road transport in the model but is certainly not a realistic assumption for the trans-European transport network (TEN-T) of northern Europe. Ideally, the average speed on each link of the congested European road network would result from a transport model. In this case, however, the simpler approach of reducing the free flow speed of each link by an empirically estimated congestion factor is chosen. A speed adjustment factor of 0.8 is used for the urban areas, while the corresponding adjustment for rural areas is 0.9. It is worth mentioning that these congestion-related speed adjustments constitute a fairly conservative estimate and in reality speeds could be further reduced 
(making road transport less attractive). Even lower speeds due to congestion have been used in the literature via speed reduction factors (Fusco et al., 2016). Lo and Hall (2006) found reductions of highway speeds up to $20 \%$ during a transit strike that would increase congestion. In our work the majority of modelled road transport is travelling in highways and we do not consider the time of travel due to lack of data.

As the objective of the road network model is to model the cost of freight transport, the transformation of the physical measurements (transport distances and time) into monetary values is important. This is done by calculating a generalized cost for traversing each link expressed as the summation of three cost contributions: distance dependent costs, time dependent costs and fare and toll costs. For road transport, the distance dependent cost component concerns vehicle operating costs (VOC) covering e.g. fuel consumption, maintenance, tires etc. The time dependent cost component consists of wages and financial costs including asset depreciation. The fare and toll costs relate to the use of a sea link, a transhipment facility or a specific infrastructure like e.g. a toll bridge, a tunnel or ring road.

\subsection{The proposed policy measures}

Zis and Psaraftis (2018a) proposed a list of measures that ship operators could use to increase their market shares, reduce their operating costs, and improve their environmental performance. Most of these measures revolved around a change of sailing speeds at the affected routes, a new sailing frequency of each service, alternating fleet deployment, and investing in abatement technologies. These measures were shown to work differently for each service, but could be useful in case of an increase of fuel prices. The very nature of SSS services however posed significant constraints on each measure. In general SSS services follow strict schedules, where a journey typically lasts an integer number of half-hours, and a ship arrives and departs at sharp or half-past hours. This is typically done to assist shippers and passengers to plan their arrival at the port on time for embarkation and disembarkation. Additional complexity was introduced by the aspired targets of ship operators on the 
capacity utilization ratios; below a certain threshold the route is unprofitable, but a very high average utilization rate has the risk of certain journeys being overbooked and thus cargoes not being picked up which harms the reliability of the service. The ship operator that provided data for this project in general considered a capacity utilization rate of $85 \%$ as optimal, which is in the range of good utilization rates as shown by Styhre (2009).

Macharis and Bontekoning (2004) conduct a literature review and provide suggestions for applications of Operations Research in intermodal freight transport research, with an objective to move cargoes from landbased modes towards intermodality.

Given the fact that certain ship operators may be less flexible in introducing changes to their services (in fear of breaching any long-term contract with their customers) more contingency plans should be developed. It is therefore imperative to consider how the other stakeholders can assist in the economic sustainability of the SSS sector. The examined policies in this work can be perceived as stimulating measures as defined by Macharis and Kin (2016), and aim to mitigate or even revert modal shifts from maritime modes (due to the SECA limits) towards conventional freight vehicles. We consider the following candidate measures that policy bodies could deploy in case of increased fuel prices, which could jeopardize the existence of SSS services and lead to modal shifts:

- full or partial internalization of external costs

- provision of subsidy towards the BAF costs of shippers utilizing SSS services

- waiving port fees for affected ship operators

- $\quad$ subsidy towards investments for emissions abating technologies

- introduction of additional tax levy on road modes

- reintroduction of ECO-Bonus systems in affected SECAs

\section{Case studies}


Most of the examined policy measures are either aiming to increase the generalized cost (GC) of transport of competing landbased modes, or to decrease the GC of the maritime options. Alternatively, some policies consider offering a subsidy towards environmental investments (thus reducing operating costs), or impose the internalization of external costs to all modes. The shipper will notice a difference if it leads to a lower GC (or higher GC in a competing mode). In the ensuing analysis we consider the following fuel price scenarios:

- Fuel Case 1 (FC1) reflecting the average observed fuel prices in 2015: HFO 263\$/ton and MGO 478\$/ton

- FC2 considers a pessimistic scenario with increased prices: HFO 533\$/ton and MGO 816 $/$ ton Figure 4 presents the modelling process in the analysis. 


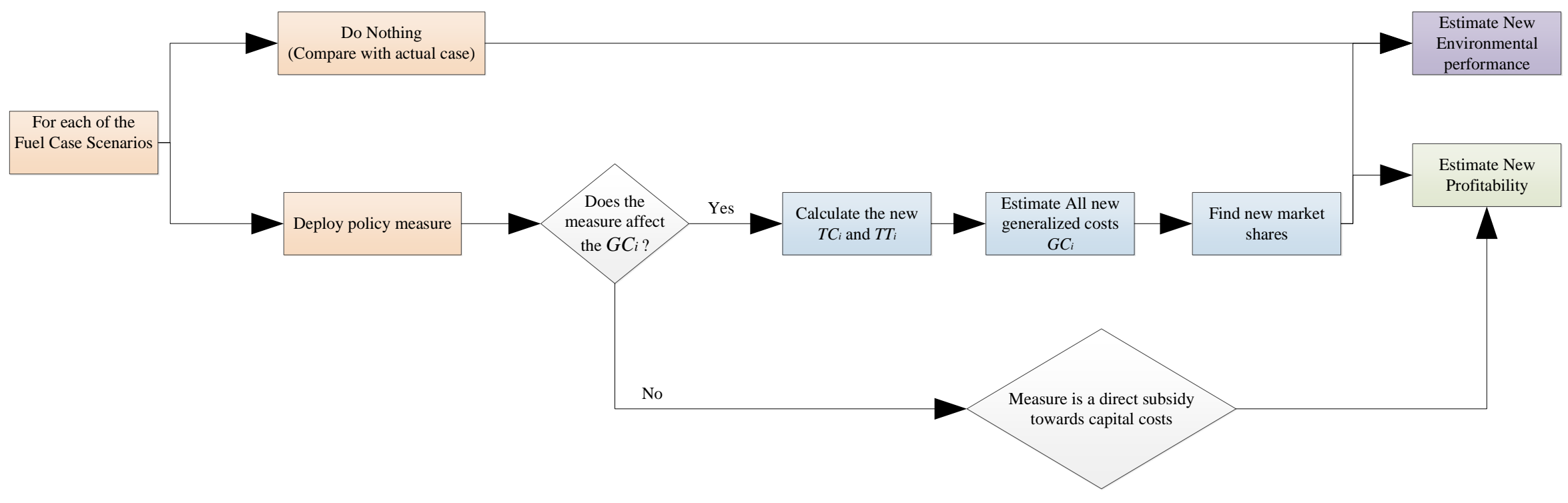

Figure 4: The modelling process of the effects of the proposed policy measures 


\subsection{The examined services}

Each measure is examined in the context of the seven SSS services examined by Zis and Psaraftis (2018a) for the sake of consistency. Data were provided by the shipping company for the years 2014 and 2015 , in order to understand the immediate impacts of the $0.1 \%$ sulphur limit. Table 1 presents a brief summary of the services, and includes the key statistics for the two periods. It can be seen that in 2015 most services show a significant reduction in fuel costs, and a small increase in revenues which is in accordance with the very positive financial outcome of 2015 for the SSS sector. Finally, Table 1 shows that the shipping company had invested heavily in scrubber systems in anticipation for the sulphur limit. 
Table 1: Overview of examined services and key statistics for 2014 and 2015. Data Source: Adapted from Zis and Psaraftis (2018a)

\begin{tabular}{|c|c|c|c|c|c|c|c|c|c|c|c|c|}
\hline Route & $\begin{array}{l}\text { Type of } \\
\text { service }\end{array}$ & $\begin{array}{l}\text { Distanc } \\
\text { e (NM) }\end{array}$ & $\begin{array}{c}\text { Speed } \\
\text { (knots) }\end{array}$ & $\begin{array}{c}\text { Number of } \\
\text { weekly } \\
\text { sailings }\end{array}$ & $\begin{array}{c}\text { Abatement } \\
\text { Options }\end{array}$ & Year & $\begin{array}{l}\text { Trips } \\
\text { Total }\end{array}$ & $\begin{array}{c}\text { Competing } \\
\text { Transport } \\
\text { modes }\end{array}$ & $\begin{array}{c}\text { Transported } \\
\text { Cargo } \\
\text { change }(\%)\end{array}$ & $\begin{array}{c}\text { Freight } \\
\text { Rate } \\
\text { change } \\
(\%)\end{array}$ & $\begin{array}{c}\text { Revenue } \\
\text { Change } \\
(\%)\end{array}$ & $\begin{array}{c}\text { Fuel Costs } \\
\text { Change } \\
(\%)\end{array}$ \\
\hline \multirow[t]{2}{*}{ Gothenburg - Ghent } & \multirow[t]{2}{*}{$\begin{array}{l}\text { Ro-Ro } \\
\text { (only } \\
\text { cargo) }\end{array}$} & \multirow[t]{2}{*}{577} & \multirow[t]{2}{*}{18.1} & \multirow[t]{2}{*}{6} & \multirow[t]{2}{*}{$\begin{array}{l}\text { Scrubbers } \\
\text { (3 vessels) }\end{array}$} & 2014 & 553 & $\begin{array}{c}\text { Maritime } \\
\text { (Gothenburg } \\
- \text { Kiel) } \\
\end{array}$ & \multirow[t]{2}{*}{6.06} & \multirow[t]{2}{*}{-5.62} & \multirow[t]{2}{*}{0.09} & \multirow[t]{2}{*}{-52.89} \\
\hline & & & & & & 2015 & 569 & Land-based & & & & \\
\hline \multirow[t]{2}{*}{ Esbjerg - Immingham } & \multirow{2}{*}{$\begin{array}{l}\text { Ro-Ro } \\
\text { (only } \\
\text { cargo) }\end{array}$} & \multirow[t]{2}{*}{326} & \multirow[t]{2}{*}{18.1} & \multirow[t]{2}{*}{6} & \multirow{2}{*}{$\begin{array}{l}1 \text { Scrubber } \\
1 \mathrm{MGO}\end{array}$} & 2014 & 512 & $\begin{array}{l}\text { Maritime } \\
\text { (same) }\end{array}$ & \multirow[t]{2}{*}{19.46} & \multirow[t]{2}{*}{-0.5} & \multirow[t]{2}{*}{18.85} & \multirow[t]{2}{*}{-15.29} \\
\hline & & & & & & 2015 & 580 & Land-based & & & & \\
\hline \multirow{2}{*}{$\begin{array}{l}\text { Rotterdam - } \\
\text { Felixstowe }\end{array}$} & \multirow{2}{*}{$\begin{array}{l}\text { Ro-Ro } \\
\text { (only } \\
\text { cargo) }\end{array}$} & \multirow[t]{2}{*}{121} & \multirow[t]{2}{*}{16.1} & \multirow[t]{2}{*}{16} & \multirow{2}{*}{$\begin{array}{l}2 \text { Scrubber } \\
1 \mathrm{MGO}\end{array}$} & 2014 & 1514 & $\begin{array}{c}\text { Maritime } \\
\text { (same) }\end{array}$ & \multirow[t]{2}{*}{15.13} & \multirow[t]{2}{*}{0.5} & \multirow[t]{2}{*}{15.71} & \multirow[t]{2}{*}{-24.34} \\
\hline & & & & & & $\begin{array}{l}2015 \\
2014\end{array}$ & & Land-based & & & & \\
\hline Copenhagen - Oslo & $\begin{array}{c}\text { Cruise } \\
\text { (Pax and } \\
\text { some } \\
\text { Cargo) } \\
\end{array}$ & 272 & 15.5 & 7 & $\begin{array}{l}1 \text { Scrubber } \\
1 \mathrm{MGO}\end{array}$ & $\begin{array}{l}2014 \\
2015\end{array}$ & $\begin{array}{l}687 \\
702\end{array}$ & Land-based & -5.82 & 1.58 & 4.28 & -9.36 \\
\hline & Ro-Pax & & & & & 2014 & 611 & & & & & \\
\hline Klaipeda-Kiel & $\begin{array}{l}\text { (Pax and } \\
\text { cargo) }\end{array}$ & 397 & 18.4 & 6 & 2 Scrubber & 2015 & 615 & Land-based & -4.64 & -7.71 & -8.89 & -30.05 \\
\hline Klaipeda - Karlshamn & $\begin{array}{c}\text { Ro-Pax } \\
\text { (Pax and } \\
\text { cargo) } \\
\end{array}$ & 223 & 17.2 & 7 & $\begin{array}{l}1 \text { Scrubber } \\
1 \mathrm{MGO}\end{array}$ & $\begin{array}{l}2014 \\
2015\end{array}$ & $\begin{array}{l}717 \\
710\end{array}$ & $\begin{array}{c}\text { Other } \\
\text { Maritime }\end{array}$ & 3.64 & -2.32 & 3.73 & -22.99 \\
\hline Dover-Calais & $\begin{array}{c}\text { Ro-Pax } \\
\text { (Pax and } \\
\text { cargo) } \\
\end{array}$ & 26 & 15.3 & 99 & $2 \mathrm{MGO}$ & $\begin{array}{l}2014 \\
2015\end{array}$ & $\begin{array}{l}6210 \\
4994\end{array}$ & $\begin{array}{l}\text { Land-based } \\
\text { (Eurotunnel) }\end{array}$ & -17.66 & 9.36 & -18.04 & -50.35 \\
\hline
\end{tabular}




\subsection{Internalization of external costs}

This measure considers the full or partial internalization of external costs associated with the transportation along the examined routes and by the various modes used. In the examined case studies, the external costs will be added to the transport cost element in the generalized cost formulation used in the modal shift models. Various specifications will be considered for the internalization process. The effects of the added costs on the final generalized cost of transport for the different routes, as well as on the new modal balance will be discussed. Figure 5 presents the process of examining the impacts of a potential internalization of external costs, as a measure to combat the negative effects of the low sulphur fuel requirements.

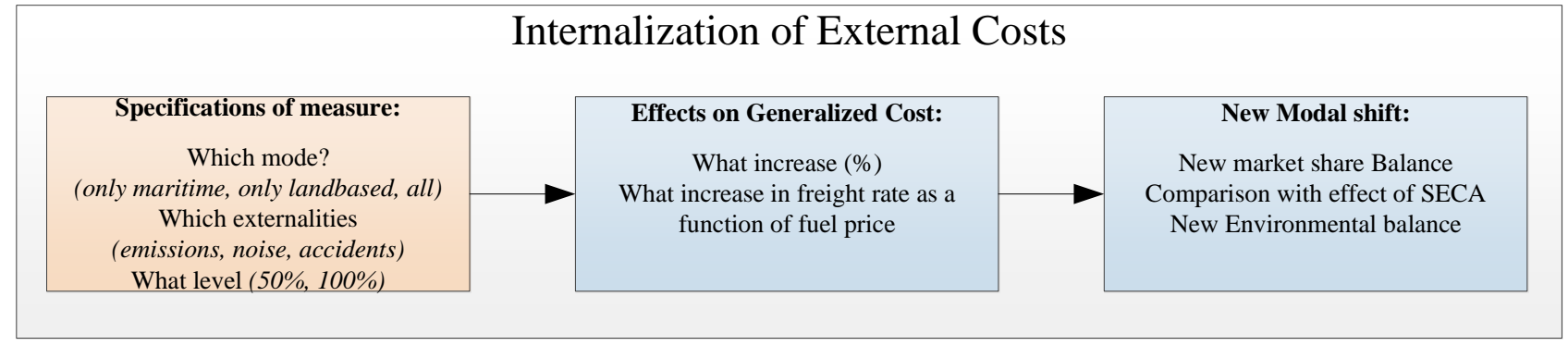

Figure 5: The internalization of external costs as a potential policy measure

External cost estimates should include a price for emissions, noise, accidents, congestion, as well as infrastructure maintenance and damages. According to the 2014 Handbook (Ricardo-AEA, 2014) that has been selected as the primary source of information, the only external costs pertaining to maritime transport are those of climate change and air pollution. The Handbook does not differentiate among different maritime modes (e.g. liner shipping, bulk, Ro-Ro). Therefore, these costs will have to be calculated on the basis of the fuel consumption data obtained directly from the vessels employed and the unit values ( $€$ per kg) of the pollutants that the Handbook provides. The unit value figures of Table 2 labeled as 'Medium' are those of the Handbook inflated from 2010 to 2015. The 'Low' and 'High' figures are estimates of the Danish Ministry of Transport, Building and Housing. They are not used in the analysis but have been added simply to show the width of variation. Table 2 also presents the external costs of road transport (in $€ /$ vehicle $\cdot$ kilometre). 
Table 2: External cost estimates (road figures in $€$ per vehicle kilometre). Source: Own compilation

\begin{tabular}{|c|c|c|c|c|c|c|c|}
\hline \multirow{2}{*}{ Pollutant } & \multicolumn{3}{|c|}{$\begin{array}{c}\text { Unit values in } € / \mathrm{kg} \text { of } \\
\text { pollutant }\end{array}$} & \multicolumn{2}{|c|}{ Sea region } & \multicolumn{2}{|c|}{$\begin{array}{l}\text { Other external costs } \\
\text { (road diesel truck) }\end{array}$} \\
\hline & Low & Medium & High & $\begin{array}{l}\text { Baltic } \\
\text { Sea }\end{array}$ & $\begin{array}{l}\text { North } \\
\text { Sea }\end{array}$ & \multicolumn{2}{|c|}{ Average Europe } \\
\hline $\mathrm{CO}_{2}$ & 0.0070 & 0.1104 & 0.2061 & \multirow{2}{*}{\multicolumn{2}{|c|}{0.1104}} & $\begin{array}{l}\text { Climate } \\
\text { change }\end{array}$ & \\
\hline & & & & & & Air Pollution & 0.0899 \\
\hline $\mathrm{PM}_{2.5}$ & 4.6390 & 50.1542 & 1568.3829 & 17.4762 & 32.673 & $\begin{array}{c}\text { Noise } \\
\text { Accidents }\end{array}$ & $\begin{array}{l}0.1026 \\
00152\end{array}$ \\
\hline $\mathrm{NO}_{\mathrm{v}}$ & 00043 & 134744 & 542781 & 5052 & 7535 & Congestion & 0.5138 \\
\hline$N_{x}$ & 0.0043 & 13. & 54.2 & 5.95 & 1.5 & Infrastructure & 0.0659 \\
\hline $\mathrm{SO}_{\mathrm{x}}$ & 1.4199 & 12.9691 & 167.2566 & 6.6486 & 9.6246 & Total & 0.8732 \\
\hline
\end{tabular}

In the following calculations for land-based modes the medium unit values will be used, whereas for maritime options the sea region values will be used. We also provide medium estimates on other external costs that are only applicable on road transport. These are average figures that can be used at a macro level. The actual costs vary with the exact routes that the road vehicles take, as they depend on population exposure among other parameters. It is also worth noting that congestion is the most costly externality for road transport, accounting for almost $60 \%$ of total external costs.

\subsubsection{Visualizing the effects of internalization of external costs}

As shown in Table 2, the full internalization of all external costs for road vehicles would cost an additional $0.8732 €$ per vehicle-kilometer. A typical user cost for road diesel vehicles in Europe (with eastern European drivers) amounts to $1 € /$ vehicle-kilometer, so it is evident that the internalization would significantly increase the transportation costs of land-based options. For the maritime options, we assume that all emissions are always attributed to the cargo even though that would not be realistic in an internalization scenario. For the maritime modes, the emissions at the port are considered for $\mathrm{CO}_{2}, \mathrm{SO}_{\mathrm{x}}, \mathrm{NO}_{\mathrm{x}}$ and $\mathrm{PM}_{2.5}$ emissions, while at the sailing phases only the $\mathrm{CO}_{2}$ emissions are internalized. Figure 6 summarizes the cost of internalization per unit transport compared to the freight rate of each route. The first graph shows the actual freight rates from the shipping company in 2015 (FC1), while the second presents what the freight rates would have been under higher fuel prices (FC2). The external costs of FC2 
would also be different due to the lower utilization rate, and thus increased emissions intensity for the cargoes.

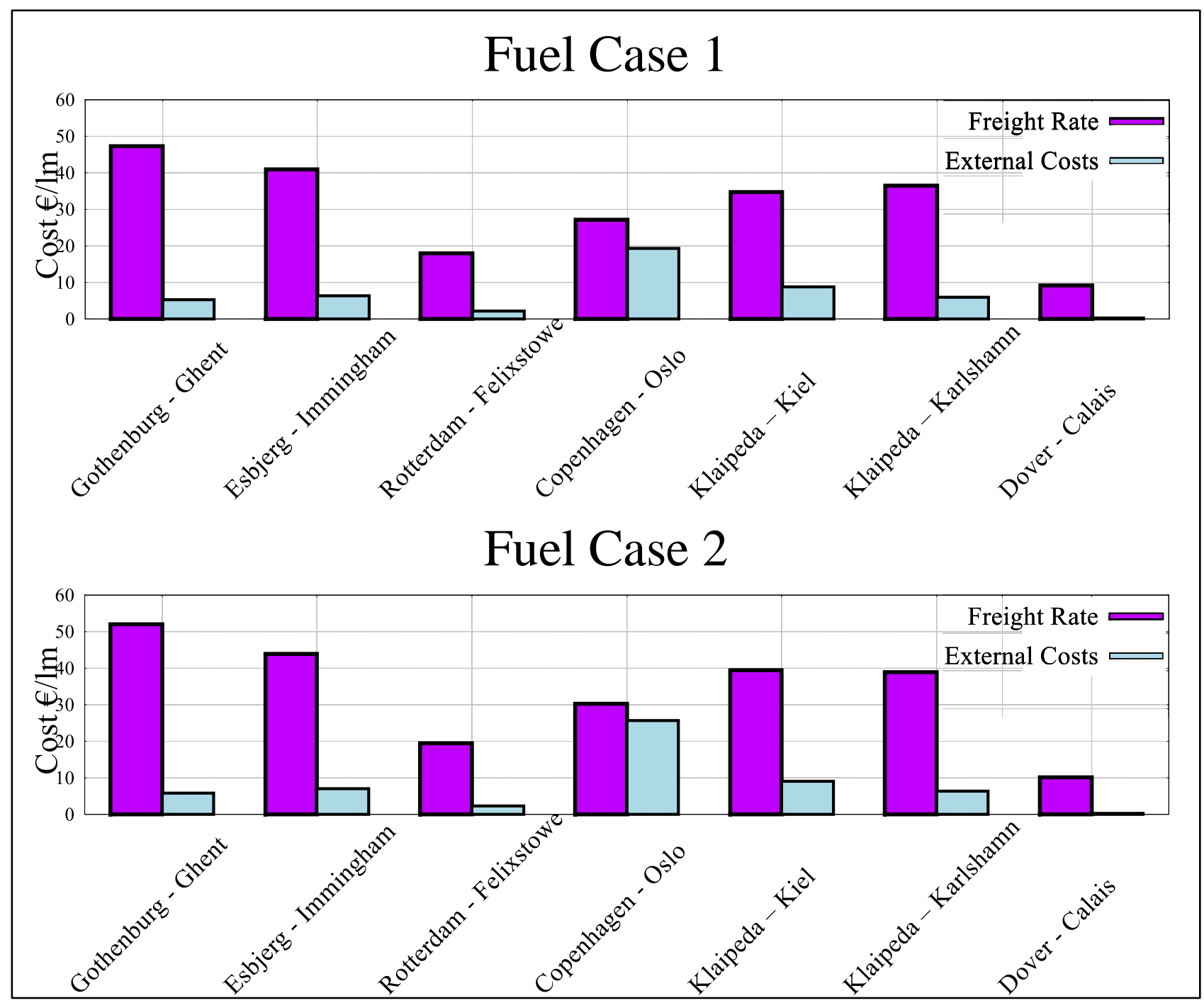

Figure 6: Cost (€/lanemeter) of internalization of emissions for each route vs freight rate

It is evident that for the cargo-only (Ro-Ro) routes the external costs are between 10 and $16 \%$ of the freight rate for both fuel case scenarios. Therefore the impact of internalizing external costs is lower for maritime modes than it is for road options. The actual costs of internalization would be lower for Ro-Pax services considering that a part of the emissions would be allocated to passengers. The effects of the full internalization of external costs in the supply chain can be visualized using the GIS tool described in Section 3.3. Using Gothenburg as the origin, the accumulated cost of transport towards all possible destinations using the least expensive route can be illustrated on a map which we call an 
isocost map. This cost will be increasing as the distance from the origin is growing. Figure 7 shows the effects of internalizing the external costs using a differential map, which is the product of subtracting the isocost map before and after the internalization process.

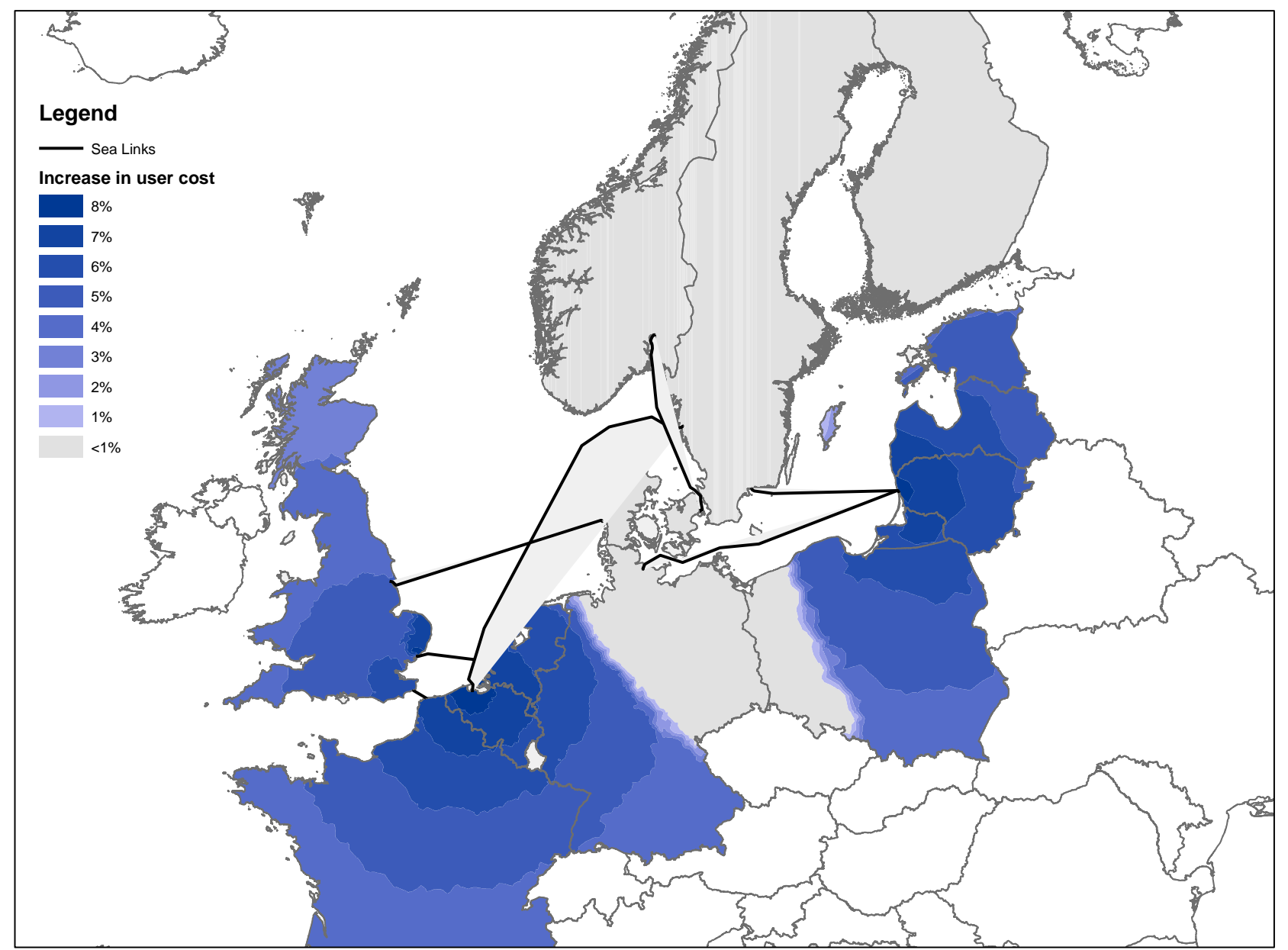

Figure 7: Differential map centered on Gothenburg. The black lines represent maritime links

Figure 7 illustrates not only the areas where the intermodal transport chain from Gothenburg using the sea links is competitive but also indicates how the competitiveness changes when the external costs of maritime modes are internalized. The different intervals correspond to the relative increase in total user cost due to the internalization of all external costs for the sea links. The grey areas are the areas where land-based truck transport is most competitive both before and after the internalization of the external cost. In the blue areas, the intermodal transport chain is still competitive, but the relative user cost of the transport increases from 1-8\% making intermodal transport less competitive. 


\subsubsection{Effects of external cost internalization on modal shifts}

In general, the internalization of external costs due to air emissions leads to a significant increase in total external costs per lane meter. The Gothenburg - Ghent route is an illustrative example. Table 3 summarizes the impacts of internalizing these costs on the market shares of each mode along this route.

Table 3: Effects of internalization of external costs on modal share for Gothenburg - Ghent for 1 year (569 trips)

\begin{tabular}{|c|c|c|c|c|c|c|}
\hline \multirow[b]{3}{*}{$\begin{array}{c}\text { Internalization } \\
\text { Level }(\%)\end{array}$} & \multicolumn{5}{|c|}{$\begin{array}{c}\text { Fuel Case } 1 \\
\text { Maritime external cost } € 5.35 / \mathrm{lm} \\
\text { Land-based external cost (full): } € 0.04851 / \mathrm{lm} \cdot \mathrm{km}\end{array}$} & \\
\hline & \multicolumn{3}{|c|}{ New Market Share (\%) } & \multicolumn{3}{|c|}{ policy Revenue (M€) } \\
\hline & $\begin{array}{l}\text { Maritime } \\
\text { (Gothenburg } \\
\text { - Ghent) }\end{array}$ & $\begin{array}{c}\text { Maritime } \\
\quad \text { (via } \\
\text { Gothenburg } \\
\text { - Kiel) }\end{array}$ & $\begin{array}{l}\text { Land- } \\
\text { Based }\end{array}$ & $\begin{array}{c}\text { Gothenburg } \\
\text { - Ghent } \\
\text { (Maritime } \\
\text { only) }\end{array}$ & $\begin{array}{c}\text { Gothenburg } \\
\text { - Ghent } \\
\text { (Maritime } \\
\text { and road } \\
\text { segment) }\end{array}$ & $\begin{array}{c}\text { All } \\
\text { three } \\
\text { options } \\
\text { all } \\
\text { modes }\end{array}$ \\
\hline 0 & 32.1 & 29.8 & 38.1 & NA & NA & NA \\
\hline 50 & 47 & 29.5 & 23.5 & 6.98 & 13.3 & 94.1 \\
\hline 100 & 61.2 & 25.9 & 12.9 & 18.15 & 34.61 & 143.38 \\
\hline \multicolumn{7}{|c|}{$\begin{array}{l}\text { Fuel Case } 2 \\
\text { itime external cost } € 5.84 / \mathrm{lm} \\
\text { external cost (full): } € 0.04851 / \mathrm{lm} \cdot \mathrm{km}\end{array}$} \\
\hline & \multicolumn{3}{|c|}{ New Market Share (\%) } & \multicolumn{3}{|c|}{ policy Revenue (M€) } \\
\hline $\begin{array}{c}\text { Internalization } \\
\text { Level (\%) }\end{array}$ & $\begin{array}{l}\text { Maritime } \\
\text { (Gothenburg } \\
\text { - Ghent) }\end{array}$ & $\begin{array}{c}\text { Maritime } \\
\quad \text { (via } \\
\text { Gothenburg } \\
\text { - Kiel) }\end{array}$ & $\begin{array}{l}\text { Land- } \\
\text { Based }\end{array}$ & $\begin{array}{c}\text { Gothenburg } \\
\text { - Ghent } \\
\text { (Maritime } \\
\text { only) }\end{array}$ & $\begin{array}{c}\text { Gothenburg } \\
\text { - Ghent } \\
\text { (Maritime } \\
\text { and road } \\
\text { segment) }\end{array}$ & $\begin{array}{c}\text { All } \\
\text { three } \\
\text { options } \\
\text { all } \\
\text { modes }\end{array}$ \\
\hline 0 & 30 & 30.8 & 39.2 & NA & NA & NA \\
\hline 50 & 44.5 & 30.8 & 24.7 & 7.72 & 14.13 & 105.17 \\
\hline 100 & 58.7 & 27.4 & 13.9 & 20.36 & 37.27 & 162 \\
\hline
\end{tabular}


Table 3 shows the effects of a hypothetical internalization of external costs in the Gothenburg - Ghent service. Under Fuel Case 1, for a 50\% internalization the policy cost for shippers using the Gothenburg-Ghent route would be 6.98 M€ and for a 100\% internalization 18.15 M€ (only for the maritime leg), or 13.3 M€ and 34.61 M€ respectively if the external costs of the road segments are also included. The total policy revenue refers to the additional costs of transportation for all shippers using any of the three competing modes if the external costs were monetized and paid. The total policy revenue is not affected much by the different fuel price scenarios as it is proportional to the total emissions generated, and we assume that the total (all modes) transported volumes are not changed if fuel prices increase. It is noteworthy that for the high fuel price scenario, the external cost of the maritime leg (in $€ / \mathrm{lm}$ ) is increasing due to the lower load factor of the vessel as a result of the market loss. In both the partial (50\%) and full internalization, it is evident that the maritime option with the shortest road leg (maritime mode has $100 \mathrm{~km}$ of road leg on average, vs $500 \mathrm{~km}$ on the competing maritime option through Gothenburg - Kiel) would actually increase its transport demand, mainly due to the much higher external costs for the road option used in this case. For other routes examined a full internalization would result in almost a complete shift to maritime modes (particularly when the competing landbased option covers long road distances). In such scenarios, there would actually be a need to deploy more vessels in the affected services. It should also be mentioned that such an internalization would significantly increase the freight rates for all options, and as a result there would be a reduction in the total transportation demand, which cannot be calculated with the developed models.

\subsection{Subsidizing the extra costs for shippers via the BAF}


This measure proposes the provision of subsidies to the shippers in order to cover the additional BAF surcharges they are paying in the freight rate set from the ship operator. Since the $1^{\text {st }}$ of January 2015 , the ship operator that has provided the data for this study has included the price differential between ultra-low sulphur fuel oil and HFO in the calculation, thus effectively increasing the freight rates for shippers due to the regulation. The calculation is always conducted based on the fuel price differential between the MGO ( $0.1 \%$ sulphur content) price in Rotterdam, and the HFO ( $1 \%$ sulphur content) price during October-November 2014. The exact final amount depends also on the sailing distance, frequency, speed, and whether the ship is Ro-Ro or Ro-Pax. In order to model the effect of the BAF on each of the examined routes, a model was constructed that predicts the additional BAF surcharge for each of the routes, as a function of fuel price for MGO $0.1 \%$ only. Table 4 shows the BAF surcharges for the two fuel price scenarios for each route, as well as the total cost of subsidizing the extra costs for all shippers selecting the respective services.

Table 4: Impacts of subsidizing the BAF premium on the examined routes

\begin{tabular}{|c|c|c|c|c|c|c|c|c|c|c|c|c|c|c|}
\hline \multirow{2}{*}{$\begin{array}{l}\text { Rout } \\
\text { e } \\
\text { Fuel } \\
\text { Case }\end{array}$} & \multicolumn{2}{|c|}{$\begin{array}{c}\text { Gothenbur } \\
\text { g Ghent }\end{array}$} & \multicolumn{2}{|c|}{$\begin{array}{c}\text { Esbjerg } \\
\text { Immingha } \\
\text { m }\end{array}$} & \multicolumn{2}{|c|}{$\begin{array}{l}\text { Rotterda } \\
\text { m } \\
\text { Felixstow } \\
\text { e }\end{array}$} & \multicolumn{2}{|c|}{$\begin{array}{c}\text { Copenhage } \\
\mathrm{n} \\
\text { Oslo }\end{array}$} & \multicolumn{2}{|c|}{$\begin{array}{c}\text { Klaipeda } \\
\text { Kiel }\end{array}$} & \multicolumn{2}{|c|}{$\begin{array}{c}\text { Klaipeda } \\
\text { Karlsham } \\
\text { n }\end{array}$} & \multicolumn{2}{|c|}{$\begin{array}{l}\text { Dover } \\
\text { Calais }\end{array}$} \\
\hline & 1 & 2 & 1 & 2 & 1 & 2 & 1 & 2 & 1 & 2 & 1 & 2 & 1 & 2 \\
\hline $\begin{array}{l}\text { BAF } \\
(€ / 1 \mathrm{~lm} \\
\end{array}$ & $\begin{array}{c}1.3 \\
7\end{array}$ & 5.13 & 1.19 & 4.3 & $\begin{array}{c}0.4 \\
4\end{array}$ & $\begin{array}{c}1.5 \\
8\end{array}$ & 1.19 & 4.3 & $\begin{array}{c}1.7 \\
6\end{array}$ & $\begin{array}{c}6.3 \\
4\end{array}$ & $\begin{array}{c}1.0 \\
1\end{array}$ & $\begin{array}{c}3.6 \\
5\end{array}$ & $\begin{array}{c}0.3 \\
3\end{array}$ & 1.2 \\
\hline $\begin{array}{l}\text { Polic } \\
\text { y } \\
\text { Cost } \\
(\mathrm{M} €)\end{array}$ & 2.5 & $\begin{array}{c}10.0 \\
4\end{array}$ & 1.96 & 7.82 & 1.6 & $\begin{array}{c}6.4 \\
9\end{array}$ & 0.67 & 3.22 & $\begin{array}{c}2.4 \\
1\end{array}$ & $\begin{array}{c}8.9 \\
9\end{array}$ & $\begin{array}{c}1.3 \\
8\end{array}$ & $\begin{array}{c}5.3 \\
1\end{array}$ & $\begin{array}{c}2.2 \\
5\end{array}$ & $\begin{array}{c}8.5 \\
9\end{array}$ \\
\hline
\end{tabular}

Under FC2 with prices as high as in the beginning of 2014, such a policy scheme costs approximately four times what it would under FC1 for all routes except Copenhagen - Oslo where it is almost five times. It should be noted that if these subsidies were fully paid back to the shippers, then the ship operators would have captured an additional market share compared, and also increase their utilization capacity rates. However, as Table 4 illustrates a uniform policy to refund shippers would 
be extravagantly expensive each year, particularly considering there are many affected services inside the North and Baltic SECAs.

\subsection{Waiving part of port fees}

This measure is considering the option of subsidizing part of the port dues that the affected ship operators have to pay during their vessel calls. The rationale behind this measure is that since there are lower emissions as a consequence of the regulation (during the approach/departure phases) it may be reasonable to reduce the port fees by a certain extent. Retrieving information on the actual port fees for each vessel call is possible through the websites of the respective port authorities. However, it is quickly evident that the information on the tariffs are referring to a typical port call, and information on the actual tariffs for recurring vessels is not available. While most of these costs are available online, the actual costs paid by frequent callers (as in the case of Ro-Ro services) are not public. It is therefore very difficult to construct a one-size-fits-all policy for the easement of such fees. Data were retrieved on what was the percentage cost of the port fees over the total annual costs of each service during 2015. These are summarized in Table 5.

Table 5: Port fees vs fuel costs as \% of operating costs

\begin{tabular}{|l|c|c|c|}
\hline Route & $\begin{array}{c}\text { Port cost as \% of } \\
\text { operating costs }\end{array}$ & $\begin{array}{c}\text { Fuel costs as \% of } \\
\text { operating costs }\end{array}$ & $\begin{array}{c}\text { Policy cost } \\
(\mathrm{M} €)\end{array}$ \\
\hline Gothenburg - Ghent & 4.6 & 30 & 2.21 \\
\hline Esbjerg - Immingham & 4.2 & 39 & 1.54 \\
\hline Rotterdam - Felixstowe & 4.5 & 30 & 1.21 \\
\hline Copenhagen - Oslo & 4.7 & 21 & 4.02 \\
\hline Klaipeda - Kiel & 6.8 & NA & 5.49 \\
\hline Klaipeda - Karlshamn & 4.9 & 21 & 2.79 \\
\hline Dover - Calais & 14.7 & 23 & 8.04 \\
\hline
\end{tabular}

Table 5 shows that the port costs in the year are a very small component of the overall operating cost for each service, with the exception of Dover Calais with a very high number of port calls a year. An interesting comparison can be made with the percentage of fuel costs of using MGO instead of HFO over the operating costs. While some vessels have been using scrubbers and therefore are still using 
HFO, for a ship operator with a similar cost structure, the MGO-HFO differential price would amount to between 8 and $15 \%$ of the total operating costs, which is higher than the port fees.

If a subsidy is provided to the ship operators towards their port dues, this could amount (for a full refund) to between 1.2 and 8 million $€$ per year, which is similar for most routes to the cost of simply covering the BAF surcharges.

\subsection{ECO-bonus system}

The first ECO-bonus system was authorized by the European Commission as a temporary state aid scheme in Italy for freight operators moving from road to sea. The main objective of ECO-bonus was to establish a mechanism to promote short sea shipping, and in particular the Italian Motorways of the Sea (MoS) network (Tsamboulas et al., 2015). The first implementation of the scheme, considered the provision of $20 \%$ towards the seaway tariffs of existing (at the time) services (up to $30 \%$ for new services), while setting certain minimum limits (in terms of annual trips by the benefited operator). In Italy, two additional state aid schemes were approved from the European Commission targeting modal shifts towards rail and sea. The maritime scheme is called Marebonus, and will have a budget of $€ 138$ million that will be used for the introduction of new services, or upgrades to existing sea routes (European Commission, 2016). Finally, work on an ECO-bonus like system is currently conducted by the MED-Atlantic ecobonus project (co-funded by the EC) that seeks to increase the use of MoS in the Western Mediterranean and Atlantic markets. This section considers the annual costs of providing a subsidy of $20 \%$ of the freight rate paid in each service for all customers (new and old) during 2015, and the impact this would have on the market shares of the examined service. We compare the market share of the Ro-Ro operator for both fuel price scenarios if there is no policy action, with the case of providing the $20 \%$ subsidy. 


\begin{tabular}{|c|c|c|c|c|c|}
\hline Route & $\begin{array}{c}\text { \% Market } \\
\text { Share } \\
(2014)\end{array}$ & \multicolumn{2}{|c|}{$\begin{array}{c}\text { Fuel Case } 1 \\
(\% \text { Market Share }-2015)\end{array}$} & \multicolumn{2}{|c|}{$\begin{array}{c}\text { Fuel Case } 2 \\
(\% \text { Market Share }-2015)\end{array}$} \\
\hline & & Do nothing & $\begin{array}{l}\text { Provide } 20 \% \text { of } \\
\text { freight rate to } \\
\text { shipper }\end{array}$ & Do nothing & $\begin{array}{l}\text { Provide } 20 \% \text { of } \\
\text { freight rate to } \\
\text { shipper }\end{array}$ \\
\hline $\begin{array}{c}\text { Gothenburg } \\
\text { - Ghent }\end{array}$ & 30.5 & 32.1 & 37.85 & 30 & 35.99 \\
\hline \multicolumn{2}{|c|}{ Total Policy Cost } & \multicolumn{2}{|c|}{$\mathrm{M} € 19.88$} & \multicolumn{2}{|c|}{$\mathrm{M} € 21.86$} \\
\hline $\begin{array}{c}\text { Esbjerg - } \\
\text { Immingham }\end{array}$ & 64.1 & 64.5 & 78.1 & 58.4 & 74.4 \\
\hline \multicolumn{2}{|c|}{ Total Policy Cost } & \multicolumn{2}{|c|}{$\mathrm{M} € 15.75$} & \multicolumn{2}{|c|}{$\mathrm{M} € 17.83$} \\
\hline $\begin{array}{l}\text { Rotterdam - } \\
\text { Felixstowe }\end{array}$ & 26.3 & 26.1 & 37 & 23.1 & 34 \\
\hline \multicolumn{2}{|c|}{ Total Policy Cost } & \multicolumn{2}{|c|}{ M€ 17.65} & \multicolumn{2}{|c|}{ M€ 19.52} \\
\hline $\begin{array}{c}\text { Copenhagen } \\
\text { - Oslo }\end{array}$ & 21.8 & 18.7 & 29.4 & 14.1 & 24.1 \\
\hline \multicolumn{2}{|c|}{ Total Policy Cost } & \multicolumn{2}{|c|}{ M€ 4.34} & \multicolumn{2}{|c|}{$\mathrm{M} € 5.27$} \\
\hline $\begin{array}{c}\text { Klaipeda - } \\
\text { Kiel }\end{array}$ & 55.7 & 57.1 & 60.3 & 54.9 & 58.6 \\
\hline \multicolumn{2}{|c|}{ Total Policy Cost } & \multicolumn{2}{|c|}{ M€ 9.88} & \multicolumn{2}{|c|}{ M€ 11.29} \\
\hline $\begin{array}{l}\text { Klaipeda - } \\
\text { Karlshamn }\end{array}$ & 70 & 71.5 & 82 & 66.9 & 79.3 \\
\hline \multicolumn{2}{|c|}{ Total Policy Cost } & \multicolumn{2}{|c|}{$\mathrm{M} € 11.15$} & \multicolumn{2}{|c|}{$\mathrm{M} € 12.36$} \\
\hline $\begin{array}{l}\text { Dover - } \\
\text { Calais }\end{array}$ & 43.4 & 42.8 & 46.7 & 41 & 45.3 \\
\hline \multicolumn{2}{|c|}{ Total Policy Cost } & \multicolumn{2}{|c|}{$M € 13.62$} & \multicolumn{2}{|c|}{$\mathrm{M} € 15.07$} \\
\hline
\end{tabular}

The results of Table 6 indicate that such as scheme would be very successful in attracting additional customers using the Ro-Ro links, however the cost would be particularly high if it was applied to all shippers. The subsidy increases the market share comparably for both fuel price scenarios, and for 
FC2 the total policy costs for each service are not increasing as much as in the other policy measures examined. This is due to the fact that the subsidy is calculated based on the freight rate (of which the BAF is only a small part) and the higher subsidy in FC2 is offset by the loss of market share to landbased options. Therefore, such a scheme would actually work better in high fuel price scenarios, though the total cost can be very high for certain services. In case a pilot implementation was considered, whereby the refund would be provided only to new users of the link, the cost would be proportionally lower. It is clear that such a policy would have an objective of increasing the users of maritime services, and not simply to reverse the negative effects of the low-sulphur regulation, as the monetary incentive exceeds the actual surcharge imposed on shippers because of low-sulphur fuel use. A subsidy of a different level could also be considered as a potential measure.

\subsection{Subsidies for abatement technologies}

From the operator's perspective, the main question in such investments is the net present value and the length of the payback period. Certain operators invested early on in scrubber systems, years in advance of the new limit. Through the MoS programme, the European Commission assisted operators via subsidies towards the capital investment costs for the retrofits. Initially the subsidies amounted to $20 \%$ of the total installation costs, which were subsequently increased to $30 \%$ as of 2014 . For five of its vessels, the ship operator that provided data for this work had secured subsidies amounting to $6.3 \mathrm{M} €$ from the European Commission, under the MoS programme. A policy that provides such subsidies will not have a direct influence on modal shift, as the freight rates are not affected by it. However, in the future such measures may reduce the payback period of such environmental investments by effectively reducing the size of initial capital requirements. Table 7 presents the total cost that such a policy would incur, for the retrofit of the vessels deployed in each of the examined routes (assuming no vessel swapping, and that only the maximum number of vessels deployed in a peak-week are retrofitted). 
Table 7: Costs towards scrubber retrofits

\begin{tabular}{|c|c|c|}
\hline Service & Number of vessels & Subsidy for scrubbers retrofit (million $€$ ) \\
\hline Gothenburg - Ghent & 3 & $2.4-4.8$ \\
\hline Esbjerg - Immingham & 2 & $1.6-3.1$ \\
\hline Rotterdam - Felixstowe & 3 & $2.6-5.2$ \\
\hline Copenhagen - Oslo & 2 & $1.9-3.8$ \\
\hline Klaipeda - Kiel & 2 & $1.9-3.8$ \\
\hline Klaipeda - Karlshamn & 2 & $1.7-3.4$ \\
\hline Dover - Calais & 2 & $1.8-3.5$ \\
\hline
\end{tabular}

The variations are due to the different estimates on the cost for a scrubber retrofit per installed engine power on each vessel. The total costs for such a policy are significant if applied to all of the deployed vessels in the examined services. Considering the number of affected services and the available fleet, such a policy would be very costly. However, these funds would only be paid once and there could be an additional requirement that all ship operators that received such subsidies would in turn reduce their BAF surcharges on shippers.

\subsection{Tax on land-based modes}

This measure considers the identification of the necessary increase in the land-based freight rates that a shipper must pay, in order to negate the modal shift loss that is triggered by the low sulphur fuel requirement. It is evident that this is a very case specific measure, as the necessary increase per landbased transport work (in lm-NM units) will depend on the relative weight of the maritime costs in the generalized cost of the shipper. The required increases in land-based costs are summarized in percentage terms in Table 8, for two fuel price scenarios. For the Dover - Calais service, the percentage increase refers to the Eurotunnel cost. For Klaipeda - Karlshamn this measure was not considered due to the lack of competition with landbased options. 


\begin{tabular}{|l|c|c|c|c|}
\hline Route & $\begin{array}{c}\text { Fuel Case } \\
1\end{array}$ & $\begin{array}{c}\text { Total Cost (M€) for } \\
\text { shippers (all modes) }\end{array}$ & $\begin{array}{c}\text { Fuel Case } \\
2\end{array}$ & $\begin{array}{c}\text { Total Cost (M€) for } \\
\text { shippers (all modes) }\end{array}$ \\
\hline Gothenburg - Ghent & 3.83 & 51.42 & 14.47 & 201.8 \\
\hline Esbjerg - Immingham & 2.48 & 135.38 & 8.95 & 488.2 \\
\hline Rotterdam - Felixstowe & 15.18 & 239 & 23.76 & 374 \\
\hline Copenhagen - Oslo & 6.06 & 52.79 & 21.85 & 190.39 \\
\hline Klaipeda - Kiel & 3.53 & 100.5 & 12.68 & 361.3 \\
\hline $\begin{array}{l}\text { Dover - Calais } \\
\text { (Eurotunnel increase) }\end{array}$ & 2.12 & 3 & 7.74 & 10.94 \\
\hline
\end{tabular}

For high fuel prices, the required increased in landbased transportation costs to offset the modal shifts is significant. There is significant variation observed that can be attributed to different road distances for each landbased alternative to the examined services. The much higher increase requirements for Rotterdam - Felixstowe (very short maritime leg), Copenhagen-Oslo (predominantly a passenger service) and Gothenburg - Ghent (more alternatives) can be attributed to the fact that for these routes the landbased option have low generalized cost for freight. In terms of policy costs these would be extremely high, proportional to the amount of cargo transported, and even higher for routes that compete with long landbased alternatives, and for heavily loaded services. For the case of Eurotunnel, the total policy costs are as expected much lower as the assumption is that the maritime services only compete with the rail option and the road segments for the shipments are the same regardless of which mode the shipper chooses. Similar analysis should be conducted on other short sea shipping services in order to identify an optimal flat levy on landbased options. This levy could lead to net modal shifts towards SSS modes.

\section{Conclusions and further research}

This paper conducted a literature review on previous work on SSS and on the impacts of SECAs in maritime shipping, both fields that have seen increased academic attention in recent years. A set of policy options was analysed to mitigate and avert the negative impacts of the low SECA limits on Ro-Ro services. 


\subsection{Main insights}

The impacts of SECAs on SSS were not as dramatic as expected, but to some extent freight rates have increased due to the lower sulphur limits. Previous work had shown that operators can also adapt to the new situation by altering their sailing schedules (in terms of speed, sailing frequency, and network design), but that may not be sufficient if fuel prices increase. For a policy measure to be successful, essentially it is a question of how to mitigate the effects of the BAF surcharges due to the low sulphur requirements. Table 9 compares the total costs for each of the proposed policy actions. 
Table 9: Comparison of total policy costs (M€) for each of the examined services with fuel prices of 2015 (FC 1)

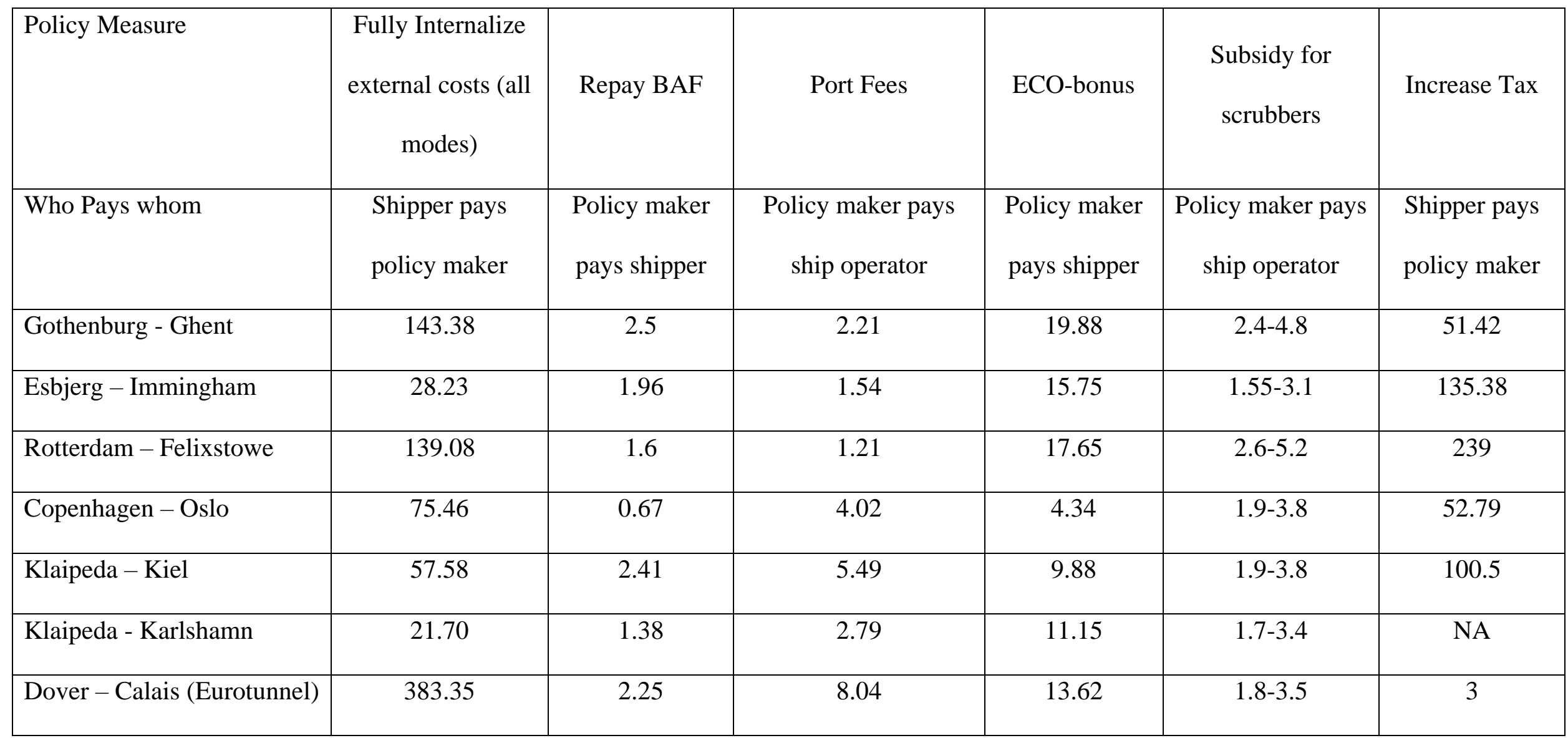


It is evident that the total costs borne by shippers in case of a full internalization of external costs, or an increase on landbased costs via a tax, are extremely high. These funds could then in theory be used to offset emissions via investments in clean energy (similar to $\mathrm{CO}_{2}$ offsets in the airline sector). For the internalization measure, all transport modes would become more expensive, but due to the lower external costs of short sea shipping in comparison with road modes, maritime modes would be attracting more market shares. For the increase on landbased costs, the shippers would again have to pay significantly more in the landbased options so as to nullify the modal shifts caused by the lower SECA limits. The overall higher shipper costs would have to be then passed on to the consumers leading to potentially lower transported volumes due to cost increases. The current modelling framework is not able of assessing such impacts. The ECO-bonus system with a $20 \%$ subsidy towards all shippers is also a very costly measure for the policy maker. However, the measure can be successful in attracting more shippers to maritime modes, and would be interesting if only applied to shippers shifting cargoes from landbased options (provided of course such shift can be documented), but unfair towards existing shippers using maritime modes. In general, distortions to competition should be avoided.

From the remaining examined policy measures, which have already been tested in some form, the typical annual costs for full mitigation range between 1 - $4 \mathrm{M€}$ per route (except port fees in the Dover - Calais case), but can increase significantly for high fuel prices scenarios as these measures are sensitive to fuel prices. As a general observation, subsidizing the shipper vs subsidising the ship operator (e.g. for installing scrubbers) have comparable costs and are easier to monitor. In addition, a subsidy towards ship operators to invest in green technologies could come with a requirement to lower the freight rates (for example remove the BAF surcharges) and make it a win-win case for every stakeholder. The proposed policy measures can also be combined with operator's measures as 
proposed by Zis and Psaraftis (2018a), and that could potentially cause a positive modal shift from land-based options to maritime services.

\subsection{Future Research}

It can be argued that SSS operators in Northern Europe caught a lucky break with the low fuel prices since 2014 until 2018, and the expected storm never hit them. Similar regulations that are targeting environmental impacts of the sector can be expected to affect key stakeholders in various ways. Indeed, the introduction of the Energy Efficiency Design Index (EEDI), the potential expansion of emission trading schemes (ETS) to cover emissions from the shipping sector, as well as the introduction of the global $0.5 \%$ sulphur cap, can all have the potential of being game changers. Particularly for scrubber systems, the coming of the global sulphur cap in 2020 is expected to raise the demand for such technologies, especially if the low-sulphur fuel availability is not enough to cover the necessary demand. However, a turn of the industry to scrubber technologies may in turn potentially increase the demand for HFO in contrast to what is anticipated, and thus raise its price and reduce the fuel price differential with $0.5 \%$ sulphur fuel (and thus the benefit of investing in scrubber systems). Therefore, the impacts of environmental policies are much more complicated and difficult to predict, as it has been shown with the lowering of sulphur limits within SECAs. It is therefore vital to propose policies that mitigate the possible negative impacts of such a regulation which will (post 2020) affect more severely the whole shipping sector and not just the relatively niche SSS. Competition of Ro-Ro with the generally faster Lo-Lo services is also a topic worthy of investigation. Therefore there are important research questions to be examined ahead of the global sulphur cap. The different levels of fuel availability will have impacts on ship operators' decisions to invest in abatement technologies. The anticipated increased operating costs due to the sulphur cap may lead to a reduction in sailing speeds in the different shipping markets, which may in turn affect freight rates. These can also have significant ramifications on modal shifts on sectors beyond the Ro-Ro services 
examined here, particularly with the new emerging links such as the One Belt One Road (OBOR) initiative. For instance and with the anticipated fuel price increases in 2020 and beyond, and the anticipated speed drop as a result, one could envision a scenario in which cargoes from Far East to Europe and vice versa are more encouraged to use land.-based routes vis-à-vis maritime routes. The question here is how serious such a modal shift might be. The work presented in this paper can be used as an initial step towards answering some of these research questions.

\section{Acknowledgements}

The work presented in this paper is in the context of the project: "Mitigating and reversing the sideeffects of environmental legislation on Ro-Ro shipping in Northern Europe" funded by the Danish Maritime Fund. The authors are grateful to a manager of the Ro-Ro shipping company whom we worked with in this project, for the provision of data and valuable input in producing this paper, and who wishes to remain anonymous. The authors would like to thank the two anonymous reviewers for their feedback and comments in improving this manuscript.

\section{References}

Andersson, H., Fagerholt, K., \& Hobbesland, K. (2015). Integrated maritime fleet deployment and speed optimization: Case study from RoRo shipping. Computers \& Operations Research, 55, 233 240.

Bjornland, D. (1993). The importance of short sea shipping in European Transport. ECTM, Short Sea Shipping, Economic Research Center.

Brons, M., \& Christidis, P. (2012). External cost calculator for Marco Polo freight transport project proposals, Call 2012 version. JRC Scientific and Policy Reports. European Commission, Brussels.

Brynolf, S., Magnusson, M., Fridell, E., \& Andersson, K. (2014). Compliance possibilities for the future ECA regulations through the use of abatement technologies or change of fuels.

Transportation Research Part D: Transport and Environment, 28, 6-18.

Chang, Y-T., Lee, P. T-W., \& Suthiwartnarueput, K. (2016). Editorial: External costs in transportation and logistics. International Journal of Shipping and Transport Logistics, Vol. 8, No. 6. 
Crainic, T. G. (2000). Service network design in freight transportation. European Journal of Operational Research, 122(2), 272-288.

Cullinane, K., Bergqvist, R., 2014. Emission control areas and their impact on maritime transport. Transportation Research Part D: Transport and Environment, 28, 1-5.

Cullinane, K., \& Cullinane, S. (2013). Atmospheric Emissions from Shipping: The Need for Regulation and Approaches to Compliance, Transport Reviews, 33:4, 377-401.

Douet, M., \& Cappuccilli, J. F. (2011). A review of short sea shipping policy in the European Union. Journal of Transport Geography, 19(4), 968-976.

European Commission (2016). Press release. State aid: Commission approves public funding to promote move of freight transport from road to rail and sea in Italy. Available at: http://europa.eu/rapid/press-release_IP-16-4461_en.htm (accessed June 2018)

European Commission (2011). WHITE PAPER. Roadmap to a Single European Transport Area Towards a competitive and resource efficient transport system. COM(2011) 144, Brussels, 28.3.2011.

Fusco, G., Colombaroni, C., \& Isaenko, N. (2016). Short-term speed predictions exploiting big data on large urban road networks. Transportation Research Part C: Emerging Technologies, 73, 183201.

García-Menéndez, L., Martínez-Zarzoso, I., \& De Miguel, D. P. (2004). Determinants of mode choice between road and shipping for freight transport: evidence for four Spanish exporting sectors. Journal of Transport Economics and Policy (JTEP), 38(3), 447-466.

Guelat, J., Florian, M., \& Crainic, T. G. (1990). A multimode multiproduct network assignment model for strategic planning of freight flows. Transportation science, 24(1), 25-39.

Hanssen, T. E. S., Mathisen, T. A., \& Jørgensen, F. (2012). Generalized transport costs in intermodal freight transport. Procedia-Social and Behavioral Sciences, 54, 189-200.

Holmgren, J., Nikopoulou, Z., Ramstedt, L., \& Woxenius, J. (2014). Modelling modal choice effects of regulation on low-sulphur marine fuels in Northern Europe. Transportation Research Part D: Transport and Environment, 28, 62-73.

Jourquin, B., \& Beuthe, M. (1996). Transportation policy analysis with a geographic information system: the virtual network of freight transportation in Europe. Transportation research part c: emerging technologies, 4(6), 359-371.

Jiang, L., Kronbak, J., \& Christensen, L. P. (2014). The costs and benefits of sulphur reduction measures: Sulphur scrubbers versus marine gas oil. Transportation Research Part D: Transport and Environment, 28, 19-27.

Lemper, B., Hader, A., Hübscher, A., Maatsch, S., \& Tasto, M. (2009). Reducing the sulphur conten of shipping fuels further to $0.1 \%$ in the North Sea and Baltic Sea in 2015: Consequences for shipping in this shipping area. Final report. Institut für Seeverkehrswirtschaft und Logistik. Bremen. 
Lo, S. C., \& Hall, R. W. (2006). Effects of the Los Angeles transit strike on highway congestion. Transportation Research Part A: Policy and Practice, 40(10), 903-917.

Lo, W. W. L., Wan, Y., \& Zhang, A. (2015). Empirical estimation of price and income elasticities of air cargo demand: The case of Hong Kong. Transportation Research Part A: Policy and Practice, 78, 309-324.

Macharis, C., \& Bontekoning, Y. M. (2004). Opportunities for OR in intermodal freight transport research: A review. European Journal of operational research, 153(2), 400-416.

Macharis, C., \& Kin, B. (2017). The 4 A's of sustainable city distribution: Innovative solutions and challenges ahead. International Journal of Sustainable Transportation, 11(2), 59-71.

Maibach M., Schreyer C., Sutter D., van Essen H.P., Boon B.H., Smokers R., Schroten A., Doll C., Pawlowska B. \& Bak M. (2008). Handbook on estimation of external costs in the transport sector. IMPACT study. Delft, CE.

Medda, F., \& Trujillo, L. (2010). Short-sea shipping: an analysis of its determinants. Maritime Policy \& Management, 37(3), 285-303.

Meixell, M. J., \& Norbis, M. (2008). A review of the transportation mode choice and carrier selection literature. The International Journal of Logistics Management, 19(2), 183-211.

Mulligan, R. F., \& Lombardo, G. A. (2006). Short sea shipping. WMU Journal of Maritime Affairs, 5(2), 181-194.

Odgaard, T., Frank, C., Henriques, M., \& Bøge, M., (2013). The impact on Short Sea Shipping and the Risk of Modal Shift from the Establishment of an NOx Emission Control Area, North Sea Consultation Group, Available at:

http://mst.dk/media/90033/Theimpactonshortseashippingandtheriskofmodalshiftfromtheestablishme ntofaNECAfina\%20(1).pdf (accessed June 2015)

Paixão Casaca, A. C., \& Marlow, P. B. (2009). Logistics strategies for short sea shipping operating as part of multimodal transport chains. Maritime Policy \& Management, 36(1), 1-19.

Panagakos, G. P., Stamatopoulou, E. V., \& Psaraftis, H. N. (2014). The possible designation of the Mediterranean Sea as a SECA: A case study. Transportation Research Part D: Transport and Environment, 28, 74-90.

Ricardo-AEA (2014). Update of the Handbook on External Costs of Transport. Report for the European Commission DG MOVE, London.

Southworth, F., \& Peterson, B. E. (2000). Intermodal and international freight network modeling. Transportation Research Part C: Emerging Technologies, 8(1-6), 147-166.

Styhre, L. (2009). Strategies for capacity utilisation in short sea shipping. Maritime Economics \& Logistics, 11(4), 418-437.

Suárez-Alemán, A., Trujillo, L., \& Medda, F. (2015). Short sea shipping as intermodal competitor: a theoretical analysis of European transport policies. Maritime Policy \& Management, 42(4), 317334. 
Sys, C., Vanelslander, T., Adriaenssens, M., \& Van Rillaer, I. (2016). International emission regulation in sea transport: Economic feasibility and impact. Transportation Research Part D: Transport and Environment, 45, 139-151.

Tichavska, M., \& Tovar, B. (2017). External costs from vessel emissions at port: a review of the methodological and empirical state of the art. Transport Reviews, 37:3, 383-402.

Tsamboulas, D., Chiappetta, A., Moraiti, P., \& Karousos, I. (2015). Could Subsidies for Maritime Freight Transportation Achieve Social and Environmental Benefits? The Case of Ecobonus. Transportation Research Record: Journal of the Transportation Research Board, (2479), 78-85.

United Nations Conference on Trade and Development (2018) Review of maritime transport. UNCTAD/RMT/2018, United Nations publication.

http://unctad.org/en/PublicationsLibrary/rmt2018_en.pdf, accessed November 2018

Vanherle, K., \& Delhaye, E. (2010). External costs of maritime transport. Brussels: European Community of Ship owners' Associations (ECSA).

Zis, T., Angeloudis, P., Bell, M. G., \& Psaraftis, H. N. (2016). Payback Period for Emissions Abatement Alternatives: Role of Regulation and Fuel Prices. Transportation Research Record: Journal of the Transportation Research Board, (2549), 37-44.

Zis, T., \& Psaraftis, H. N. (2017). The implications of the new sulphur limits on the European RoRo sector. Transportation Research Part D: Transport and Environment, 52, 185-201.

Zis, T., \& Psaraftis, H. N. (2018a). Operational measures to mitigate and reverse the potential modal shifts due to environmental legislation. Maritime Policy \& Management, 1-16.

Zis, T., \& Psaraftis, H. N. (2018b). Key performance indicators to assess and reverse the negative impacts of SECAs policies for Ro-Ro shipping. FME Transactions, 46(3), 347-354.

Zissis, D., Saharidis, G. K., Aktas, E., \& Ioannou, G. (2018). Emission reduction via supply chain coordination. Transportation Research Part D: Transport and Environment, 62, 36-46. 